\title{
ПРОГРАМА ПСИХОЛОГІЧНОГО СТИМУЛЮВАННЯ САМОАКТУАЛІЗАЦЇ ОСОБИСТОСТІ МАЙБУТНІХ ФАХІВЦІВ
}

УДК:159.923.2

\section{Михайленко Лілія Миколаӥвна}

Кандидат психологічних наук, дочент, дочент кафедри психології Мелітопольського державного педагогічного університету імені Богдана Хмельницького, м. Мелітополь (Україна)

\section{Гніпель Дар'я Іаорівна}

Студентка 4 курсу Мелітопольського державного педагогічного університету імені Богдана Хмельницького, м. Мелітополь (Україна)

\begin{abstract}
Анотація. В статті представлені результати розробки та апробації тренінгової програми психологічного стимулювання процесу самоактуалізації особистості студентів у процесі їх професійної підготовки, на прикладі майбутніх психологів та педагогів, адже самоактуалізація є одним з критерїв ефективності діяльності психолога (педагога), головним інструментом у його роботі з клієнтом (вихованцем). Програма представляє корекційну складову технології самоактуалізаиії особистості. Основою прикладного аспекту програми служив погляд на самоактуалізацію як акмеологічну інваріанту психолога (педагога) - одну з компонент структури його професіоналізму, що зумовлюе оптимальний творчий потенціал та високу продуктивність пращчі. Тренінгова програма спрямована на актуалізацію потреби особистості майбутніх фахівців у самопізнанні та саморозумінні, формуванні імпульсу для їх подальшого саморозвитку. У структуру програми входило два блоки: інформаційний $i$ тренінговий, реалізовані на десяти заняттях. Перше заняття присвячено формуванню групи, моніторингу иілей учасників, останнє-рефлексії учасників щзодо програми, решта вісім - основним рисам самоактуалізуючої особистості - креативності, контактності, відповідальності, автономності, самоприйняттю, глибинності переживань, синергічності, сенсу життя. Результати апробачії програми засвідчили особистісне зростання студентів як загалом, так $i$ за окремими компонентами. В статті намічаються шляхи подальшого вивчення теми.
\end{abstract}

Ключові слова: тренінг, стимулювання, самоактуалізаџія, розвиток, особистість, професійна підготовка.

Постановка проблеми. На сьогоднішній день питання самоактуалізації молоді $€$ дуже важливим і актуальним, оскільки людина, яка прагне до саморозвитку, набагато лег- 
ше робить свій життєвий вибір, вона більш активна і відповідальна за власні дії, більш креативна й ефективна у нестандартних життєвих ситуаціях, тобто вона більш творча. У студентські роки процес самоактуалізації набуває особливої інтенсивності, тому що саме в юнацькому віці людина усвідомлює власну індивідуальність і несхожість на інших. У цьому віці остаточно складається фундамент ціннісних орієнтацій, визначається перелік головних напрямів життєдіяльності, пошуків, самореалізації тощо. Професійні інтереси, різноманітні уподобання, стиль поведінки, характер взаємодії та спілкування - всі ці складові способу життя закладаються саме у період навчання у ВН3.

Дослідженню проблем саморозвитку, самоактуалізації і самореалізації особистості присвячено роботи представників гуманістичної психології - А. Маслоу, Р. Мея, Г. Олпорта, К. Роджерса, В. Франкла та ін. [13]. У центрі наукової уваги гуманістичних психологів знаходиться здорова творча особистість, метою якої $\epsilon$ самоактуалізація (самореалізація).

У вітчизняній психології проблему розвитку та формування особистості представлено концепціями Б. Ананьєва, К. АбульхановоїСлавської, Л. Анциферової, І. Беха, Л. Божович, О. Бондаренка, М. Боришевського, Б. Братуся, I. Булах, Л. Виготського, , Г. Костюка, О. Леонтьєва, С. Максименка, О. Орлова, В. Роменця,
С. Рубінштейна, В. Татенка, Т. Титаренко та iн. [10].

Окремі аспекти проблеми самоактуалізації особистості частково досліджувались у працях М. Боднар [2], М. Гасюк [3], В. Гупаловської [4], Ю. Долінської [5], 3. Карпенко [6]. Водночас відсутні порівняльні дослідження самореалізації майбутніх фахівців у різних сферах професійної діяльності, не приділяється достатньої уваги для пошуку можливостей стимулювання процесу самоактуалізації. Актуальність дослідження цих аспектів проблеми самоактуалізації особистості на етапі іiі професійного становлення є незаперечною.

\section{Проблематика роботи та мета дос-}

лідження. Мета нашого дослідження полягала в розробці та апробації програми психологічного стимулювання самоактуалізації особистості студентів різного фаху, спрямованої на актуалізацію потреби особистості майбутніх фахівців у самопізнанні та саморозумінні, формуванні імпульсу для їх подальшого саморозвитку. Запропонована програма представляє корекційну складову технології самоактуалізації особистості та іiї можна класифікувати як вид тренінгу особистісного зростання. Аудиторія учасників може бути досить різноманітною. Найбільш оптимальною є група учасників від 8 до 12 осіб.

В нашому дослідженні проведена апробація програми «Психологічне стимулювання самоактуалізації особистості майбутніх фахів- 
ців» на прикладі підготовки майбутніх психологів та педагогів, адже самоактуалізація є одним 3 критеріїв ефективності діяльності психолога (педагога), головним інструментом у його роботі з клієнтом (вихованцем). Основою прикладного аспекту програми служив погляд на самоактуалізацію як акмеологічну інваріанту психолога (педагога) - одну з компонент структури його професіоналізму, що зумовлює оптимальний творчий потенціал та високу продуктивність праці.

Виклад основного матеріалу і резульmamiв дослідження. У структуру програми входило два блоки: інформащійний $і$ тренінговий, реалізовані на дванадцяти заняттях (таблиця 1). Перше заняття тренінгового блоку присвячено формуванню групи, моніторингу цілей учасників, останнє - рефлексії учасників щодо програми, решта вісім - основним рисам самоактуалізуючої особистості - креативності, контактності, відповідальності, автономності, самоприйняттю, глибинності переживань, синергічності, сенсу життя. Структура кожного заняття включала три елементи: 1) знайомство $з$ характеристиками певної риси, яка пророблялася, пояснення змісту і цілей теми, вправи для «розминки»; 2) основна частина; 3) рефлексія теми в цілому [1], [7], [11].

Складання програми стимулювання базувалось на таких принципах:

$\Rightarrow$ врахування теоретичних основ феномена самоактуалізації особистості;

$\Rightarrow$ орієнтованість на психологічні особли- вості юнацького віку;

$\Rightarrow$

застосування методик та вправ, що припускають різноваріантне ставлення до предмету та результатів обговорення;

$\Rightarrow$ динамічність, цікавість та смислова цінність занять.

Першим етапом втілення програми «Психологічне стимулювання самоактуалізації особистості майбутніх фахівців» була робота 3 активізації самопізнання шляхом реалізації інформаційного блоку, що складався 3 двох етапів. На етапі прагнення було створено мотивацію на відвідування занять у експериментальній групі з метою активізації у студентів бажання змінити себе. На етапі усвідомлення активізація самопізнання студентів здійснювалася шляхом ознайомлення їх 3 основними положеннями гуманістичної теорії, поглядами на розвиток особистості як класиків, так і сучасних вчених, що переймаються проблемою самоактуалізації особистості, в межах тем «Самоактуалізація особистості як процес оптимізації, стимулювання, збагачення змісту розвитку майбутнього фахівця» та «Обмеження та перешкоди самоактуалізації особистості».

На першому занятті інформаційного блоку «Самоактуалізація особистості як процес оптимізації, стимулювання, збагачення змісту розвитку майбутнього фахівця» студенти ознайомились 3 основними принципами та етичними підходами гуманістичної психологіï: 
Структура та зміст програми «Психологічне стимулювання самоактуалізації особистості майбутніх фахівців»

\begin{tabular}{|c|c|c|c|}
\hline Тема заняття & Мета заняття & Вправи та завдання & पac (xB.) \\
\hline \multicolumn{4}{|c|}{ Інформаційний блок } \\
\hline $\begin{array}{l}\text { 1. «Самоактуалізація особистості } \\
\text { як процес оптимізації, стимулю- } \\
\text { вання, збагачення змісту розви- } \\
\text { тку майбутнього фахівця» }\end{array}$ & $\begin{array}{l}\text { ознайомити з основними прин- } \\
\text { ципами та етичними підходами } \\
\text { гуманістичної психології }\end{array}$ & $\begin{array}{l}\text { 1. Концепція самоактуалізації особистості А. Маслоу: основ- } \\
\text { ні положення, умови, особливості процесу } \\
\text { 2. Анкета «Якості самоактуалізованої особистості у мене» }\end{array}$ & 50 \\
\hline $\begin{array}{l}\text { 2. «Обмеження та перешкоди } \\
\text { самоактуалізації особистості» }\end{array}$ & $\begin{array}{l}\text { ознайомити з механізмами пси- } \\
\text { хологічного захисту }\end{array}$ & $\begin{array}{l}\text { 1. Вплив захисних механізмів на темпи самоактуалізації } \\
\text { особистості } \\
\text { 2. «Діагностика типологій психологічного захис- } \\
\text { ту» (Р. Плутчик) }\end{array}$ & 40 \\
\hline \multicolumn{4}{|c|}{ Тренінговий блок } \\
\hline 1. Формування групи (2 год.) & $\begin{array}{l}\text { сформувати мотивовану групу } \\
\text { учасників тренінгу }\end{array}$ & $\begin{array}{l}\text { 1. Мета тренінгу } \\
\text { 2. Моніторинг цілей } \\
\text { 3. Лист до себе - } \\
\text { 4. Знайди однодумців } \\
\text { 5. Екзистенційні цінності } \\
\text { 6. Рівень співвідношення «цінності» і «доступності» (за } \\
\text { Е. Фанталовою) } \\
\text { 7. Домашнє завдання }\end{array}$ & $\begin{array}{l}15 \\
20 \\
15 \\
20 \\
20 \\
30\end{array}$ \\
\hline 2. Креативність (2 год.) & $\begin{array}{l}\text { уміти розкривати свій потен- } \\
\text { ціал, бути життєтворчим }\end{array}$ & $\begin{array}{l}\text { 1. Привітання } \\
\text { 2. Клинопис } \\
\text { 3. Мозковий штурм } \\
\text { 4. Розмова з долею } \\
\text { 5. Мультфільм } \\
\text { 6. Загадка семи мудреців }\end{array}$ & $\begin{array}{c}10 \\
5 \\
10 \\
30 \\
45 \\
20\end{array}$ \\
\hline 3. Контактність (4 год.) & $\begin{array}{l}\text { сформувати уміння викликати } \\
\text { довіру до себе, цінувати міжо- } \\
\text { собистісні стосунки як джере- } \\
\text { ло життєвого досвіду та досві- } \\
\text { ду саморозуміння }\end{array}$ & $\begin{array}{l}\text { 1. Молекули } \\
\text { 2. «Зірки на небі»- } 1 \\
\text { 3. Візитка } \\
\text { 4. Розмова без слів } \\
\text { 5. «Рідна душа» і «душа компанії» } \\
\text { 6. Моя улюблена гра } \\
\text { 7. Риси контактної людини } \\
\text { 8. Пазли } \\
\text { 9. Зірки на небі - } 2\end{array}$ & $\begin{array}{c}5 \\
15 \\
8 \\
5 \\
25 \\
35 \\
25 \\
10 \\
15\end{array}$ \\
\hline 4. Відповідальність (2 год.) & $\begin{array}{l}\text { навчити сприймати рішення } \\
\text { не лише як завершення неми- } \\
\text { нучих подій, а й як початок } \\
\text { нового ланцюга вчинків }\end{array}$ & $\begin{array}{l}\text { 1. «Чародій і горіхи» } \\
\text { 2. Незакінчені речення } \\
\text { 3. Формула відповідальності } \\
\text { 4. Вибір відповідальності } \\
\text { 5. Творчий потенціал }\end{array}$ & $\begin{array}{l}15 \\
40 \\
30 \\
35 \\
35\end{array}$ \\
\hline 5. Автономність (4 год.) & $\begin{array}{l}\text { навчити умінню довіряти собі } \\
\text { і бути цікавим для себе самого }\end{array}$ & $\begin{array}{l}\text { 1. Моя формула і мій герб } \\
\text { 2. Характероутворюючі зв'язки } \\
\text { 3. Залежність } \\
\text { 4. Довіра до себе } \\
\text { 5. Я справжній, коли... } \\
\text { 6. Метафори }\end{array}$ & $\begin{array}{l}40 \\
25 \\
25 \\
35 \\
30 \\
30\end{array}$ \\
\hline 6. Самоприйняття (4 год.) & $\begin{array}{l}\text { уміти бути різним, залишаю- } \\
\text { чись самим собою }\end{array}$ & $\begin{array}{l}\text { 1. Стіна нерозуміння } \\
\text { 2. Аплодисменти } \\
\text { 3. Герой мультфільму } \\
\text { 4. Коло субособистостей } \\
\text { 5. Дерево мого успіху } \\
\text { 6. Неприйняття себе } \\
\text { 7. Парадокси } \\
\text { 8. Я - Місто }\end{array}$ & $\begin{array}{l}25 \\
25 \\
30 \\
50 \\
15 \\
50 \\
30 \\
40\end{array}$ \\
\hline $\begin{array}{l}\text { 7. Глибинність переживань (4 } \\
\text { год.) }\end{array}$ & $\begin{array}{l}\text { актуалізувати уміння не тільки } \\
\text { розуміти цінності, а й пережи- } \\
\text { вати їх }\end{array}$ & $\begin{array}{l}\text { 1. Дерево } \\
\text { 2. Дві краплини олії } \\
\text { 3. Аксіоми Лефевра } \\
\text { 4. Мій сенс } \\
\text { 5. Хокку } \\
\text { 6. Нобелівська премія }\end{array}$ & $\begin{array}{l}20 \\
20 \\
40 \\
25 \\
50 \\
70\end{array}$ \\
\hline 8. Синергічність (2 год.) & $\begin{array}{l}\text { здатність коригувати свою } \\
\text { сутність }\end{array}$ & $\begin{array}{l}\text { 1. Пари дуальностей } \\
\text { 2. Літопис } \\
\text { 3. Рівень домагань особистості (В. Гербачевський) } \\
\text { 4. Самооцінка особистості (В. Семиченко) } \\
\text { 5. Герой }\end{array}$ & $\begin{array}{l}15 \\
30 \\
20 \\
20 \\
40\end{array}$ \\
\hline 9. Сенс життя (4 год.) & $\begin{array}{l}\text { свідомий пошук та створення } \\
\text { сенсу }\end{array}$ & $\begin{array}{l}\text { 1. Знаки пунктуації } \\
\text { 2. Типи самовдосконалення } \\
\text { 3. Жити з останнім рішенням } \\
\text { 4. Як я планую провести наступні 1о років мого життя } \\
\text { 5. Самоактуалізована особистість } \\
\text { 5. Життєві завдання } \\
\text { 5. Дерево життя } \\
\text { 6. Психологічні рецепти }\end{array}$ & $\begin{array}{l}15 \\
25 \\
25 \\
15 \\
20 \\
60 \\
40 \\
40\end{array}$ \\
\hline 10. Рефлексія тренінгу (4 год.) & $\begin{array}{l}\text { діагностика та самодіагности- } \\
\text { ка ефективності тренінгу }\end{array}$ & $\begin{array}{l}\text { 1. Опитувальник САТ (Самоактуалізаційний тест)-2 } \\
\text { 2. Опитувальник рефлексивності } \\
\text { 3. Лист до себе-2 } \\
\text { 4. Талісман } \\
\text { 5. Лабіринт }\end{array}$ & $\begin{array}{l}40 \\
25 \\
30 \\
20 \\
15\end{array}$ \\
\hline
\end{tabular}


1. Хоча людське буття має межу, людина завжди володіє свободою і необхідною для неї незалежністю. Вона несе відповідальність за свої вчинки і є творцем власного життя.

2. Для людини найважливішим джерелом інформації є іï суб'єктивний психічний досвід, доступний їй через усвідомлення свого життя у найістотнішому для буття моменті «тут і зараз» (екзистенціальний стан).

3. Людська природа визначається не тим, що робить людина, а тим, як вона усвідомлює своє буття. Її природа ніколи не може бути визначена повністю, вона завжди прагне до безперервного розвитку, до пошуку, до реалізації можливостей.

4. Людина єдина і цілісна. Ця цілісність «Я» створює унікальний характер переживань кожної людини. У людині неможливо розділити органічне і психічне, усвідомлюване і неусвідомлюване, відчуття і думку.

5. Кожен визнає i цінує внутрішній суб' єктивний світ іншого і себе. Будь-які стани людини (біль, провина, конфлікт), складаючи іiї внутрішній досвід, повинні сприйматися доброзичливо.

Аналізуючи роботи А. Маслоу, студенти знаходили перелік умов успішної самоактуалізації особистості майбутнього фахівця: «усвідомлення власного потенціалу, сильних і слабких сторін, здібностей, бажань та прагнень; сприятливі зовнішні обставини, які не подавляють тенденцію особистості до актуалізації, а сприяють їй; відкритість особистості новим ідеям, новому досвіду, готовність ризикувати, помилятись, відмовлятись від старих звичок» [8]. Також майбутні психологи і педагоги ідентифікували вісім особливостей поведінки, що ведуть до самоактуалізації, запропоновані А. Маслоу: зібраність, здатність обрати свій шлях особистісного зростання, самосвідомість, чесність, здоровість думок, саморозвиток, вершинні переживання і відсутність «его-захистів».

Згідно А. Маслоу, самоактуалізація - це бажання стати всім, чим можливо; потреба в самовдосконаленні, в реалізації свого потенціалу. Ї̈̈ шлях важкий і пов’язаний з переживанням страху невідомості і відповідальності, але це шлях до повноцінного, внутрішньо багатого життя [8]. Для більш ефективної подорожі шляхом самоактуалізації студентів було ознайомлено з наступними особливостями людей, що самоактуалізуються:

- «ефективніше сприйняття реальності і комфортабельніші відносини з нею»;

- «прийняття (себе, інших, природи)»;

- «спонтанність, простота, природність»;

- «зосередженість на завданні» (на відміну від зосередженості на собі);

- «деяка усунутість і потреба в усамітнені»;

- «самостійність, незалежність від культури і середовища»;

- «постійна свіжість оцінки»;

- «відчуття причетності, єднання з ін- 
шими»;

- «глибші міжособистісні відносини»;

- «демократична структура характеру»;

- «розрізнення засобів і цілей, добра i зла»;

- «філософське, невороже відчуття гумору»;

- «творчість, що самоактуалізується»;

- «опір аккультурації, трансцендування будь-якої приватної культури».

Після теоретичного ознайомлення майбутніх фахівців з якостями самоактуалізуючої особистості (за А. Маслоу), ми запропонували студентам оцінити наявність цих явищ та рівень їх вираженості у себе за 10-бальною шкалою (0 - повна відсутність якості, 10 - якість виражена максимально) (таблиця 2).
Знайомство 3 гуманістичною теорією дало студентам змогу зрозуміти, що самоактуалізація - це не відсутність проблем, а рух від скороминущих і нереальних проблем до проблем реальних, що психологічне зростання це послідовне задоволення все більш «високих» потреб. Рух до самоактуалізації не може початися, поки індивідуум не звільниться від домінування нижчих потреб, таких як потреби в безпеці або пошані. Самоактуалізація має на увазі тривалість, постійну залученість в працю зростання і розвитку здібностей до максимально можливого, а не задоволення меншими можливостями. Індивідуумів, що самоактуалізуються, привертають найбільш важкі і заплутані проблеми, які вимагають максимальних і найбільш творчих зусиль. Вони

Табличя 2

\section{Якості самоактуалізованої особистості}

\begin{tabular}{|c|l|c|}
\hline № п/п & \multicolumn{1}{|c|}{ Назва якості } & Бал \\
\hline 1 & Справедливість & \\
\hline 2 & Здатність до любові & \\
\hline 3 & Доброта & \\
\hline 4 & Прийняття інших & \\
\hline 5 & Автономія та незалежність & \\
\hline 6 & Почуття гумору & \\
\hline 7 & Інтуіція та глибина почуттів & \\
\hline 8 & Відкритість та сприйнятливість & \\
\hline 9 & Прийняття себе & \\
\hline 10 & Контактність & \\
\hline 11 & Орієнтація на проблему & \\
\hline 12 & Спонтанність & \\
\hline 13 & Усвідомлення індивід. особливостей & \\
\hline 14 & Активне сприйняття реальності & \\
\hline 15 & Чесність & \\
\hline 16 & Демократичні риси характеру & \\
\hline 17 & Прийняття природних законів & \\
\hline 18 & Адаптивність & \\
\hline 19 & Творчість & \\
\hline 20 & Потреба у самоті & \\
\hline
\end{tabular}


прагнуть мати справу з невизначеністю і неоднозначністю і віддають перевагу важким завданням над легкими рішеннями. «Коли людина стає цілісною - те саме відбувається і з іï світом». Самоактуалізація є також постійним процесом розкриття своїх потенційних можливостей. Це означає застосування своїх здібностей і розуму і «робота заради того, щоб робити добре те, що ти хочеш робити». Актуалізуватися - означає ставати дійсним, фактично здійснювати свої потенційні можливості. Таким чином, самоактуалізація - це навчання співнастроюватися зі своєю власною внутрішньою природою. Це означає вирішити для себе, чи подобається тобі самому певна їжа або фільм, незалежно від думок і точок зору інших. «Не можна мудро вибирати життя, якщо ти не вмієш прислухатися до самого себе в кожен момент життя» [8].

На другому занятті інформаційного блоку «Обмеження та перешкоди самоактуалізації особистості» студентам було доведено, що значна частина дослідників шукає шляхи самоактуалізації особистості через виявлення та усунення захисних механізмів.

Поняття «психологічного захисту» було введене 3. Фрейдом як засіб розв'язання конфлікту між свідомим і несвідомим. Більшість психодинамічних теорій виходять 3 того, що основним завданням «Я» $є$ збереження балансу між зовнішніми (соціальними) силами, які діють на людину, i внутрішніми (несвідомими), і як тільки виникає напруга, то душа захищає себе за допомогою того чи іншого механізму (раціоналізації, ізоляції, витіснення і т.і.). Грунтовні дослідження феномену психологічного захисту були здійснені А. Фрейд [13].

Разом 3 тим, студенти зрозуміли, що кожен 3 механізмів психологічного захисту може виконувати як позитивні функції у збереженні балансу між Воно і Зверх-Я, а значить самоактуалізації їх особистості, так і негативHi.

Так, «его-захист», на думку А. Маслоу, $\epsilon$ внутрішньою перешкодою розвитку особистості. Для того, щоб вирішити проблеми з захистами, перш за все необхідно зрозуміти їхню сутність, спрямованість та механізм їх дії. Особистість повинна спробувати звести до мінімуму деформації, що створюються «захистами» у власній психіці [8].

Ф. Перлс описав чотири механізми, які $\epsilon$ перешкодами у самоактуалізації особистості. Це - інтроекція, проекція, злиття та ретрофлексія [9].

Незнання, невідання чинників негативної поведінки є перешкодою до особистісного зростання $з$ точки зору Б. Скіннера. Першим кроком у такому випадку є визнання, а другим - змінення поведінки, яка підтримує невідання. Знання $є$ першим кроком до розширення репертуару поведінкових форм [13].

За К. Юнгом, труднощі в актуалізації (індивідуації за автором) криються на кожному етапі цього процесу: спочатку це небезпека 
ототожнення з персоною. Якщо це відбувається - індивід прагне бути надто досконалим, ідеалізує уявлення про себе, а тому не приймає свої помилки й слабкості. Перешкоди до особистісного зростання $є$ й на інших етапах, при зустрічі з тінню, анімою чи анімусом i чим ближче до мети, тим більше цих перешкод. На кінцевих етапах може виникнути синдром «мети особистості», який полягає у тому, що індивід починає вірити у свою досконалість, втрачає зв'язок зі своєю сутністю, не розуміючи, що немає абсолютно мудрих, безгрішних і бездоганних людей [15].

Студенти побачили, що У. Джеймс [13] акцентує увагу на таких перешкодах як невідреаговані емоції, блокування чи накопичення яких веде до емоційного захворювання. Та це не означає, що їх завжди треба проявляти, оскільки це може бути шкідливим. Сильні почуття краще реалізувати в дії.

У цілому студенти зрозуміли, що всі захисти, окрім сублімації, яка дійсно знімає напругу, блокують прямий прояв потреб. Будь-який 3 цих механізмів може бути віднайдений у здоровому індивідуумі, проте їх наявність вказує, як правило, на можливі невротичні симптоми.

Т. Яценко говорить про те, що у більшості робіт психологічні захисні механізми представлені як такі, що існують автономно. Але проведені нею дослідження показали, що вони «функціонують у певній цілісній і досить динамічній системі, індивідуально неповтор- ній для кожного суб’єкта» $[16$, с. 56]. Далі автор зазначає, що самоактуалізація особистості $\epsilon$ результатом гармонізації свідомого і несвідомого у поведінці суб'єкта, «збільшення сили «Я» через опанування логіки власного несвідомого і зняття тим самим суперечностей зі свідомістю» [16, с.58].

3 метою виявлення его-захистів, що $€$ внутрішніми перешкодами самоактуалізації студентської молоді, нами було використано методику Р. Плутчика «Діагностика типологій психологічного захисту» [12]. Отримані результати показали, що студенти-психологи у більшій мірі використовували різні захисні механізми. Найчастіше вони звертались до механізмів «реактивні утворення», «регресія» та «проекція». Майбутні педагоги надали перевагу «заміщенню», «компенсації» та «проекції». Студенти переконувались, що внутрішні захисти можуть перешкоджати процесу самоактуалізації їх особистості, розумінню і прийняттю самих себе. Об'єктивне ставлення до себе, навпаки, сприятиме саморозкриттю та самовираженню, стимулюватиме процес самоактуалізації їх особистості.

Таким чином, після апробації інформаційного блоку програми «Психологічне стимулювання самоактуалізації особистості майбутніх фахівців» студенти ознайомилися 3 чинниками, що уповільнюють процес самоактуалізації їх особистості. Ознайомлення з теоретичними основами процесу самоактуалізації поглибило їх уявлення про себе і свій актуаль- 
ний стан, дало змогу відчути себе більш справжніми, аутентичними, сильними і творчими.

Одночасно з реалізацією інформаційного блоку студентам експериментальних груп було запропоновано виконати завдання тренінгового блоку. Рівні роботи тренінгу охоплювали рівень поведінки, здібностей, можливостей, переконань.

На рівні поведінки формувалися навички адекватної самооцінки і самосхвалення, а також уміння активно застосовувати набуті знання і навички у житті і нових життєвих ситуаціях зокрема. На цьому рівні більшою мірою застосовувалися техніки моделювання поведінки, або когнітивно-біхевіоральної терапії. Основна увага була акцентована на аналізі ірраціональних переконань та формуванні суджень щодо самоефективності. На рівні здібностей $i$ можливостей головним завданням було научіння позитивному і парадоксальному мисленню, уміння фіксувати дезадаптивні установки, які створюють проблеми. На цьому рівні підключалися техніки гештальт-терапії, оскільки саме гештальт-підхід пропонує людині не стільки розуміти і навчатися, скільки експериментувати 3 метою максимального розширення життєвого (соціального) простору і свободи вибору. Рівень переконань торкався питань реалістичності оцінок та уміння сприймати безоцінково, конкретизації почуття невизначеності, проблем вибору і відчуття необмеженості вибору, уміння розмірковувати над питаннями і формулювати завдання у різних системах виміру. Такі питання міг вирішити підхід, у якому основну увагу приділено «свободі волі», неутрудненому розвитку особистості, усвідомленню відповідальності за вибір життєвого шляху та формування внутрішнього світу.

Таким чином, основними принципами психотерапевтичних корекційних технік стали поняття завершеності, самоефективності, автентичності, на основі яких було сформульовано концепцію тренінгового блоку: людина, яка вірить у свою успішність, прагне більш чітко сформулювати своє життєве призначення і своє ставлення до життя та стати автентичною, справжньою, самою собою, самоактуалізованою.

Тренінговий блок проходив у два етапи. Перший етап - визнання - виявився особливо складним. Студенти вчилися відділяти свої думки, почуття та вчинки від почуття власної гідності, самооцінки, концентруватися на теперішньому, а не на минулому чи майбутньому. Студенти мали приймати себе такими, як вони $\epsilon$, припинити порівнювати, критикувати, звинувачувати себе, що зашкоджує процесу їх особистісного зростання. Другий етап тренінгового блоку - це етап вибору, що проявлявся у кожного студента індивідуально. 3 того моменту, коли студент починав 3 готовністю себе приймати, перед ним поставав вибір. Менша зосередженість на власних помилках робила його більш відкритим для нових думок та дій, відбувалася переоцінка цінностей. 
У системі розподілу ідеальних цінностей майбутніх психологів і педагогів за методикою Є. Фанталової [14] спостерігалась майже однакова картина. Вищі рангові місця посіли такі поняття, як сім'я, кохання, здоров'я, друзі. Менш значущими для студентів обох груп виступили свобода, впевненість у собі, матеріально-забезпечене життя та пізнання. Нарешті, на останніх рангових місцях опинилися такі поняття, як цікава робота, активне діяльне життя, творчість, краса природи та мистецтва. У ієрархії доступностей спостерігалась велика кількість розбіжностей у відповідях досліджуваних. Для студентівпсихологів більш доступними виявились спілкування 3 друзями, можливість отримувати знання, впевненість у своїх силах, можливість кохати та бути коханими. Майбутні педагоги вважали доступними передусім: друзів, впевненість у собі, здоров'я, кохання, пізнання.

3 метою виявлення рівня домагань студентів ми використали опитувальник В. Гербачевського [12], що зробило можливим виявити компоненти мотиваційної структури особистості опитуваних. Експериментальній оцінці рівня домагань особистості майбутніх фахівців відповідала виразність компонента самоповаги. Отримані нами дані засвідчили, що у студентів-педагогів рівень домагань дещо вищий (17,7 балів), ніж у студентівпсихологів (16,5 балів). Проте, на думку майбутніх педагогів, досягнення намічених цілей більше залежить від зовнішніх обставин і на- вколишніх людей, ніж від власних зусиль і старанності.

Для визначення змісту віддаленої часової перспективи майбутніх фахівців було використане творче завдання «Як я планую провести наступні 10 років мого життя». Більшість студентів (92\%) має позитивне уявлення про майбутнє, пов'язане з кар'єрою, коханням, створенням сім'ї, народженням дітей; негативне - 4\% студентів, які пов'язують його 3 бажанням узяти від життя все, що можна, зараз, а потім, що буде, які мають невирішені проблеми сьогодення, що затьмарюють їх уявлення про майбутнє; 4\% - студентівпсихологів та $8 \%$ студентів-педагогів нейтрально ставляться до свого майбутнього.

Також виявлено дві лінії самоактуалізації опитуваних: 92\% студентів-психологів та 96\% студентів-педагогів експериментальних груп орієнтовані на реалізацію себе як висококваліфікованих фахівців; одночасно самореалізовуватись у сімейному житті схильні 92\% майбутніх психологів та 72 \% майбутніх педагогів.

На завершальному етапі тренінгової програми було запропоновано студентам, 3 урахуванням отриманої інформації про свої психологічні особливості, описати особистість, що самоактуалізується, якими якостями, відповідними їй, вони володіють, і якими б хотіли оволодіти. Для виконання цього завдання студентам було запропоновано набір 3 200 якостей особистості, запозичений нами 3 
методики «Визначення кількісного рівня самооцінки особистості». Майбутні фахівці обрали по 10 якостей, які у них є, які необхідно поліпшити, які хотілося б мати. Коли якості було відібрано, студенти прорангували їх за ступенем значущості. Аналіз відповідей студентів показав, що вони спроможні виділити конкретні якості, які у них $є$, та які вимагають подальшої роботи. Майбутні фахівці усвідомлюють наявність перешкод та труднощів у самоактуалізації своєї особистості та намічають шляхи самовдосконалення.

3 метою перевірки ефективності використаної програми стимулювання самоактуалізації особистості майбутніх психологів і педагогів у навчально-виховному процесі здійснено кореляційний аналіз за критерієм Крамера-Уелча, який не виявив значущих відмінностей показників самоактуалізації майбутніх фахівців в контрольних групах, але показав статистичну різницю за деякими шкалами самоактуалізації в експериментальних групах. В експериментальній групі майбутніх психологів найбільші зміни відбулися за сімома шкалами опитувальника САТ на рівні $\mathrm{p} \leq 0,05$ : «підтримка» $(\mathrm{r}=3,48)$, «самоприйняття» $(\mathrm{r}=$ 2,71), «пізнавальні потреби» $(\mathrm{r}=2,63)$, «сензитивність» $(\mathrm{r}=2,43)$, «самоповага» $(\mathrm{r}=$ 2,39), «Гнучкість поведінки» ( $\mathrm{r}=2,29)$, «компетентність у часі» $(\mathrm{r}=2,17)$. У майбутніх педагогів після тренінгу статистично значущі зміни відбулися за шкалами: «підтримка» (r = 3,94), «пізнавальні потре- би» $(\mathrm{r}=2,70)$, «самоприйняття» $(\mathrm{r}=2,63)$ та «сензитивність» $(\mathrm{r}=2,29)$. Проведена нами роботи спричинила ряд особистісних змін, що ведуть до самовдосконалення, особистісного розвитку досліджуваних, але тимчасово порушують цілісність їх особистості. Цей факт вплинув на незначну зміну показників студентів за шкалами «погляд на природу людини», «синергія» та «прийняття агресії».

Результати контрольного зрізу з визначення особливостей підвищення самоактуалізації за окремими шкалами підтвердили головне припущення нашого дослідження про те, що самоактуалізація особистості майбутнього фахівця зумовлена дією внутрішніх і зовнішніх чинників, вплив яких на цей процес опосередковується рівнем соціальної активності суб’ єкта.

\section{Висновки та перспективи подальших}

досліджень. Результати апробації програми стимулювання самоактуалізації особистості майбутніх фахівців у процесі професійної підготовки засвідчили особистісне зростання студентів як загалом, так і за окремими компонентами. Таким чином, вона показала свою ефективність, можливість іiі впровадження у навчально-виховний процес. Проведене дослідження не вичерпує усіх аспектів проблеми. Вимагає вивчення психологічних особливостей процесу самоактуалізації та ії стимулювання на різних етапах онтогенезу, у різних професійних спільнотах, у представників мі- 
ського та сільського населення, різних релігійних громад тощо.

\section{Перелік використаних джерел:}

1. Битянова Н. Р. Психология личностного роста: Практическое пособие по проведению тренингов личностного роста психологов, педагогов, социальных работников. - М.: Междунар. пед. акад., 1995. - 67 с.

2. Боднар М. Б. Вплив етнопсихологічних життєвих орієнтацій на самоактуалізацію студентської молоді / М.Б. Боднар: Дис. ... канд. психол. наук: 19.00.05 / Інститут соціальної та політичної психології АПН України. - К., 2004. - 216 с.

3. Гасюк М. Б. Психологічні особливості самоактуалізації сучасної жінки: Автореф. дис. ... канд. психол. наук / Прикарпатський ун-т ім. Василя Стефаника. - ІваноФранківськ, 2003. - 20 с.

4. Гупаловська В. А. Професійна самореалізація як чинник становлення особистості жінки / В.А. Гупаловська: Автореф. дис. ... канд. психол. наук / Інститут психології ім. Г.С. Костюка АПН України. - К., 2005. - 25 с.

5. Долінська Ю. Г. Самоактуалізація особистості майбутнього психолога у процесі професійної підготовки / Ю.Г. Долінська: 19.00.07. - пед. та вікова психологія: Дис. ... канд. психологічних наук. - К., 2000. - 200 с.

6. Карпенко 3. С. Аксіологічна психологія особистості / 3.С. Карпенко. - Івано-Франківськ.: Лілея-НВ, 2009. $512 \mathrm{c}$.

7. Личность. Теории, упражнения, эксперименты / Фрейджер Р., Фейдимен Д.: Пер. с англ. - СПб.: ПраймЕВРОЗНАК, 2004. - 608 c.

8. Маслоу А. По направлению к психологии Бытия / А. Маслоу / Пер. с англ. Е.Рачковой. - М.: Изд-во ЭКСМО -Пресc, 2002. - 272 c.

9. Перлз $\Phi$. Опыты психологии самопознания (практикум по гештальттерапии). - М.: Гиль-Эстель, 1993. $-240 \mathrm{c}$.

10. Психология личности в трудах отечественных пси- хологов / Составитель Куликов Л.В. - СПб: Питер, 2000. - $480 \mathrm{c}$.

11. Рудестам К. Групповая психотерапия: Пер. с англ. - СПб.: Питер, 2000. - 384 с.

12. Сочиально-психологическая диагностика развития личности и малых групп / Фетискин Н.П., Козлов В.В., Мануйлов Г.М. - М.: Изд-во Ин-та Психотерапии, 2002. $-490 \mathrm{c}$.

13. Становление личности // Психология личности в трудах зарубежных психологов / Сост. и общая редакция А.А. Реана - СПб: Питер, 2000. - С. 65-79.

14. Фанталова Е. Б. Диагностика и психотерапия внутреннего конфликта. - Самара: Издательский дом БАХPAX - M., 2001. - 128 c.

15. Юнг К. Г. Структура психики и процесс индивидуации: Пер. с англ. / Рос. акад. наук, Ин-т психологии. М. : Наука, 1996. — 267 с.

16. Яценко Т. С. Психологічні основи групової психокорекції. - К.: Либідь, 1996. - 262 с.

\section{References (Transliteration):}

1. Bityanova N. R. Psihologiya lichnostnogo rosta: Prakticheskoe posobie po provedeniyu treningov lichnostnogo rosta psihologov, pedagogov, sotsialnyih rabotnikov. - M.: Mezhdunar. ped. akad., 1995. - 67 s.

2. Bodnar M. B. Vpliv etnopsihologIchnih zhittEvih orIEntatsIy na samoaktualIzatsIyu studentskoYi molodI / M.B. Bodnar: Dis. ... kand. psihol. nauk: 19.00.05 / Institut sotsIalnoYi ta polItichnoYi psihologIYi APN UkraYini. K., 2004. - 216 s.

3. Gasyuk M. B. PsihologIchnI osoblivostI samoaktualIzatsIYi suchasnoYi zhInki: Avtoref. dis. ... kand. psihol. nauk / Prikarpatskiy un-t Im. Vasilya Stefanika. - Ivano-FrankIvsk, 2003. - 20 s.

4. Gupalovska V. A. Profesiyna samorealIzatsiya yak chinnik stanovlennya osobistostI zhinki / V.A. Gupalovska: Avtoref. dis. ... kand. psihol. nauk / Institut psihologiyi im. G.S. Kostyuka APN Ukrayini. - K., 2005. - 25 s.

5. DolInska Yu. G. Samoaktualyzatsiya osobistosti 
maybutnogo psihologa u protsesi profesiynoyi pidgotovki / Yu.G. DolInska: 19.00.07. - ped. ta vIkova psihologIya: Dis. ... kand. psihologichnih nauk. - K., 2000. - 200 s.

6. Karpenko Z. S. AksIologIchna psihologIya osobistostI / Z.S. Karpenko. - Ivano-FrankIvsk.: LIleya-NV, 2009. $512 \mathrm{~s}$.

7. Lichnost. Teorii, uprazhneniya, eksperimentyi / Freydzher R., Feydimen D.: Per. s angl. - SPb.: PraymEVROZNAK, 2004. - 608 s.

8. Maslou A. Po napravleniyu k psihologii Byitiya / A. Maslou / Per. s angl. E.Rachkovoy. - M.: Izd-vo EKSMOPress, 2002. $-272 \mathrm{~s}$.

9. Perlz F. Opyityi psihologii samopoznaniya (praktikum po geshtaltterapii). - M.: Gil-Estel, 1993. - 240 s.

10. Psihologiya lichnosti v trudah otechestvennyih psihologov / Sostavitel Kulikov L.V. - SPb: Piter, 2000 - 480 s.

11. Rudestam K. Gruppovaya psihoterapiya: Per. s angl. SPb.: Piter, 2000. - 384 s.

12. Sotsialno-psihologicheskaya diagnostika razvitiya lichnosti i malyih grupp / Fetiskin N.P., Kozlov V.V., Manuylov G.M. - M.: Izd-vo In-ta Psihoterapii, 2002. $490 \mathrm{~s}$.

13. Stanovlenie lichnosti // Psihologiya lichnosti v trudah zarubezhnyih psihologov / Cost. i obschaya redaktsiya A.A. Reana - SPb: Piter, 2000. - S. 65-79.

14. Fantalova E. B. Diagnostika i psihoterapiya vnutrennego konflikta. - Samara: Izdatelskiy dom BAHRAH - M., 2001. - $128 \mathrm{~s}$.

15. Yung K. G. Struktura psihiki i protsess individuatsii: Per. s angl. / Ros. akad. nauk, In-t psihologii. - M. : Nauka, 1996. - $267 \mathrm{~s}$.

16. Yatsenko T.S. Psihologichni osnovi grupovoyi psihokorektsiyi. - K.: Libid, 1996. - 262 s.

\section{Mykhailenko Lilia}

PhD, Associate Professor of psychology at Khmelnitsky State Pedagogical University, Melitopol (Ukraine)

\section{Hnipel Darya}

Fourth-year student of at Khmelnitsky State Pedagogical University, Melitopol (Ukraine)

\section{EMPIRICAL MODELS RESEARCH AND COMPETITIVENESS OF PERSONALITY CHARACTERISTICS PSYCHODIAGNOSTICS}

\section{ABSTRACT}

To date, the issue of self-actualization of young people is very important and urgent, as someone who is committed to self-development, is much easier to make your life choices, it is more active and responsible for their own actions, more creative and effective in unusual situations, that is more creative.

Research problems of self-actualization and personal fulfillment dedicated representatives of humanistic psychology - Maslow, R. Mey, G. Allport, Rogers, V. Frankl and others.

Analysis of the state of the problem showed the presence of many theories of selfactualization problems, some of which were investigated in the domestic psychological science (M. Bodnar, M. Gasyuk, Hupalovska V. Yu Dolinska M. Tkalych).

The aim of our research was to develop a program of psychological testing and stimulation of self-actualization of students of various specialties, aimed at updating the individual needs of future specialists in self-knowledge and 
self-understanding, pulse shaping for subsequent self. The program is part of corrective technology self-actualization. It can be classified as a form of $\Rightarrow$ training for personal growth.

This paper demonstrated the use of the $\Rightarrow$ program «Psychological stimulation of selfactualization of future specialists» in the example of training future teachers and psychologists, because self-actualization is one of the criteria for performance psychologist (teacher), the main instrument for his work with the client (pupil). Thus, based on applied aspects of programs serving view of self-actualization as acmeological invariant psychologist (teacher) - one of the components of the structure of its professionalism, resulting in optimum creativity and high productivity.

The structure of the program consisted of two components: information and training implemented in ten classes. The first session is devoted to the formation of the group monitoring purposes participants last - reflections of participants on the program, the remaining eight main features samoaktualizuyuchoyi personality creativity kontaktnosti, responsibility, autonomy, self-acceptance, hlybynnosti experiences synerhichnosti, life philosophy. The structure of each session included three elements: 1) familiarity with the characteristics of certain features that proroblyalasya, metaphorical explanation of the content and goals of topics, exercises to «warm up»; 2) the main part; 3) Reflection theme in general.
Drawing incentive program was based on the following principles:

$\Rightarrow \quad$ consideration of the theoretical foundations of the phenomenon of self-actualization;

$\Rightarrow$ focus on the psychological characteristics of adolescence;

$\Rightarrow \quad$ the application of techniques and exercises that involve riznovariantne attitude to the subject and the discussion;

$\Rightarrow$ dynamism, curiosity and semantic value classes.

By controlling the cutoff to determine the characteristics of self raising for individual scales confirm the main assumption of our study that self-actualization future professional action caused by internal and external factors which influence this process is mediated by the level of social activity of the subject.

Results of testing programs to promote self-actualization of future professionals in the training showed personal growth of students as a whole and for individual components. Thus, it has shown to be effective, the possibility of its implementation in the educational process. The study does not cover all aspects of the problem. Requires a study of psychological features of the process of self-actualization and its stimulation at different stages of ontogeny in various professional communities, representatives of urban and rural areas, different religious communities and others. 
Key words: training, stimulation, selfactualization, development, personality, professional training.

\section{Михайленко Лилия Николаевна}

Кандидат психологических наук, доцент, доцент кафедры психологии Мелитопольського государственного педагогического университета имени Богдана Хмельницкого, г. Мелитополь (Украина)

\section{Гнипель Дарья Игоревна}

Студентка 4 курса Мелитопольського государственного педагогического университета имени Богдана Хмельницкого, г. Мелитополь (Украина)

\section{ПРОГРАММА ПСИХОЛОГИЧЕСКОГО СТИМУЛИРОВАНИЯ САМОАКТУАЛИЗАЦИИ ЛИЧНОСТИ БУДУЩИХ СПЕЦИАЛИСТОВ}

Аннотация. В статье представлены результаты разработки и апробации тренинговой программы психологического стимулирования самоактуализации личности студентов в процессе их профессиональной подготовки, на примере будущих психологов и педагогов, ведь самоактуализация является одним из критериев эффективности деятельности психолога (педагога), главным инструментом в его роботе с клиентом (воспитанником). Программа представляет коррекционную составляющую технологии самоактуализации личности. Основой прикладного аспекта программы послужил взгляд на самоактуализацию как акмеологическую инварианту психолога (педагога) - одну из компонент профессионализма, что предопределяет оптимальный творческий потенциал и высокую продуктивность труда.
Тренинговая программа направлена на актуализацию потребности личности будущих специалистов в самопознании и самопонимании, формирования импульса для их дальнейшего саморазвития. В структуру программы входило два блока: информационный и тренинговый, реализованные на десяти занятиях. Первое занятие посвящено формированию группы, мониторингу целей участников, последнее - рефлексии участников по программе, оставшиеся восемь - основным чертам самоактуализирующейся личности креативности, контактности, ответственности, автономности, самопринятию, глубинности переживаний, синергичности, смыслу жизни.

Результаты апробации программы показали личностной рост студентов как в целом, так и по отдельным компонентам. В статье намечаются пути дальнейшего изучения темы.

Ключевые слова: тренинг, стимулирование, самоактуализация, развитие, личность, профессиональная подготовка.

Дата отримання статті: 01.04.2017 Дата рекомендації до друку: 03.04.2017 